Research Paper

\title{
OVERVIEW OF INVESTIGATIONS IN ECONOMIC LOSS BY ECOSYSTEM DEGRADATION RELATING TO CLIMATE CHANGE
}

\author{
Dao Huong Giang ${ }^{1}$, Bach Quang Dung ${ }^{2}$, Dao Manh Tri ${ }^{3}$
}

\section{ARTICLE HISTORY}

Received: September 08, 2019 Accepted: October 12, 2019

Publish on: October 25, 2019

\section{ABSTRACT}

Typical ecosystems of islands and coastal areas of our country such as natural forests, corals, seagrasses and mangroves play an important role in local and social socio-economic development. Coastal ecosystems provided many uses such as energy (firewood, wood, ...), exploitation and aquaculture, food and medicine, transportation, tourism, disaster prevention, habitat of plants and animals, $\mathrm{CO}_{2}$ absorption, etc. and non-use (biodiversity, learning cultures,...). However, the impacts of climate change and sea level rise (CC, SLR) and the increase in natural disasters will change the composition of sediments, salinity and pollution levels of water, leading to degradation and threaten the survival of these ecosystems. These are the most productive ecosystems, and also the most threatened in the world. In recently, researchers around the world have built scientific methods to evaluate economic value as well as increasingly complete economic losses. A number of studies have studied the economic loss due to ecosystem degradation related to climate change in Vietnam and in the world but it is still limited. This study mainly assesses the real situation of economic losses due to ecosystem degradation under the impact of climate change in recent studies.

Keywords: Economic loss, ecosystem degradation, climate change.

\section{Introduction}

Climate change is a phenomenon of warming of the Earth's surface due to increasing concentrations of greenhouse gases $\left(\mathrm{CO}_{2}, \mathrm{CH}_{4}, \mathrm{NO}_{x}\right.$, $\mathrm{CFC}, \mathrm{HFC}$...), causing environmental fluctuations and sea level rise (SLR). According to the IPCC report (2007a), the average temperature increase of the Earth is about $0.8^{\circ} \mathrm{C}$ compared to 1850 and it is expected to increase to $1.4-6.4^{\circ} \mathrm{C}$ by 2100 , compared to previous 50 years, the rate of increase in temperature in the last 50 years has nearly doubled (IPCC, 2007). Lots of research by scientists around the world has confirmed that climate change and SLR are one of the main causes of degradation of typical natural ecosystems such as natural forests, corals, seagrasses and mangroves (An et al., 2015). Along with re-

\section{Dao Huong Giang}

Corresponding author: blue_moon_2212@yahoo.com.vn

${ }^{1}$ National Economics University, Hanoi, Vietnam

$\triangle$ Bach Quang Dung dungmmu05@gmail.com

${ }^{2}$ Vietnam Journal of Hydrometeorology, Vietnam Meteorological and Hydrological Administration, Hanoi, Vietnam

${ }^{3}$ Center of Environmental, Economics and Climate Change, Institute of Resources, Environment and Sustainable Development, Hanoi, Vietnam. 
search on ecosystem degradation, scientists have also conducted studies on the estimation of value of economic losses for typical ecosystems with evaluation methods.

Vietnam is amongst countries being mostly affected by climate change and SLR. That is a threat to Vietnam's coastal island ecosystems. In fact, Vietnam's sea and island ecosystems are now being degraded at a very fast rate. The areas with high biodiversity are gradually shrinking, the number of species and wild species is declining sharply, many genetic resources are degraded and lost and many factors show ecological imbalance. Population of plants and animals tend to move farther from shore due to changes in the structure of coastal circulation, changes in river-sea interaction in coastal estuaries and due to loss of up to $60 \%$ of natural habitats (http://www.vasi.gov.vn/).

Investigations on loss assessment (damage) in Vietnam have started since the late $20^{\text {th }}$ century and till early $21^{\text {st }}$ century. The assessment of economic value of natural resources and environmental impacts on the 1990s together with the Law of Environmental Protection (in 1993) required the identification of damage caused by pollution from environmental degradation. Studies were carried out on various projects at different levels with the common goal to determine the economic value of environmental, ecosystem and public health factors under the operation of factories, industrial zones,... in particular and environmental pollution factors due to economic development activities of each region and locality in general. However, the number of studies on economic losses due to ecosystem degradation is limited. An overview of the study of economic losses due to ecosystem degradation in the context of climate change will synthesize the methods, techniques applied and the results of relevant domestic and international studies.

2. Studies on degradation of typical ecosystems due to climate change impacts in the world and Vietnam

2.1. Typical ecosystem degradation in the context of climate change in the world

In the world, researches on ecosystem degra- dation due to climate change impacts are quite popular, especially regarding coral reef, seagrass, and mangrove ecosystems.

When seawater temperature increases rapidly, it will stimulate symbiotic algae growth, these algae almost cover the sunlight, making corals unable to photosynthesize, causing "white death" (https://www.cbd.int/). Coral reef ecosystems that were prone to degradation due to climate change, as shown by the fact that aa series of dead coral in the last two decades in the research area. Selective methods to manage marine protected areas included limiting the current degradation, protecting resilient areas, integrating climate change into marine conservation plans, management and evaluation (Brain et al., 2009). A research has shown that climate change trends such as temperature, sea level rise and increasing $\mathrm{CO}_{2}$ content would put pressure on many species of seagrasses. The surface of the water is covered, increasing turbidity and reducing light penetration to the bottom, thereby reducing the photosynthesis of seagrasses, causing seagrasses to die (Short and Neckles, 1999). Mireia et al. (2014) identified the negative effects of global warming and sea level rise on seagrass ecosystems in general and especially Zosteranoltii seagrass. Determination of the change in the distribution of this seagrass to the end of the $21^{\text {st }}$ century will begradual development towards the North about $888 \mathrm{~km}$ in appropriate habitat conditions, and will gradually disappear in the South (Mireia et al., 2014). Global changes such as sea level rise affected mangrove degradation. The sedimentation rate in the mangroves might be large enough to compensate for the current sea level rise (Field, 1995). Four mangrove response scenarios in response to sea level rise offered by Gilman et al., (2007): A. There is no relative change in sea level. There is no change in mangrove location; B. Changes in mangrove area under the impact of climate change. Mangroves enter land and the sea encroachment strongly; C. Changes in mangrove area under the impact of climate change, in case there are no obstacles to the mainland. Mangroves enter the mainland, mangroves en- 
croach upon the sea but the coast is eroded; D. Changes in mangrove area under the impact of SLR and stuck between irrigation infrastructures. Mangroves encroach upon sea but erode, land encroachment is stuck between dykes. Eventually mangroves shrink or disappear (Gilman et al., 2007). Besides, forest ecosystem is vulnerable in the context of climate change. The change in temperature, precipitation, and $\mathrm{CO}_{2}$ concentration negatively affects the photosynthesis and metabolism of plants. Climate change increases the risk of extinction of rare animals and genetic resources, increases the risk of wildfires, and spreads of diseases more widely and widely (Charlotte et al., 2007). Tropical forests are more vulnerable to the impacts of climate change, especially, young trees. Climate change can have impacts on forest health (growth, regeneration, species composition and diversity) leading to degradation and vice versa (Inkyin and $\mathrm{Su}$, 2014).

\subsection{Typical ecosystem degradation in the context of climate change in Vietnam}

In Vietnam, degradations of coral reefs, seagrasses, mangroves have been investigated from 2010. Studies evaluated the causes of degradation of ecosystems in which climate change is one of main reason. However, research on degradation of natural forest due to climate change has not been focused, mainly due to human impacts.

Yet (2010) developed a set of criteria to assess the degradation of coral, seagrass and mangrove ecosystems. Assessments of the causes and extent of degradation of coral ecosystems, seagrasses, coastal mangroves were conducted in Vietnam and their changing trends (Yet, 2010). A study completed the database of current state of primary ecosystems such ascoral reefs and mangroves of 14 research areas focusing on 5 key areas: Ha Long Bay, Ba Lat, Tam Giang - Cau Hai and Con Dao, Truong Sa Islands. This assessed and forecasted the level of degradation of the ecosystems (coral reefsand mangroves) in these study areas. The level of degradation varied foreach region. The self-recovery abilities of typical marine ecosystems were assessedin some study areas (Cuong and Thung, 2011). The project pointed out the char- acteristics of the distribution of ecosystems of coral reefs, seagrasses, mangroves and forecasted the extent of degradation according to scenarios of sea level rise of $50 \mathrm{~cm}$ and $100 \mathrm{~cm}$ in key island areas of Vietnam: Bach Long Vi, Ly Son, Con Dao and Phu Quoc (An et al., 2015). The study by Tiến (2015) evaluated the natural environment fluctuations and socio-economic vulnerability in Nhon Hoi economic zone and surrounding areas. Especially, the study forecasted the fluctuations of ecosystems (coral reefs, seagrasses and mangroves) in the study area with the scenarios of climate change, sealevel-rise $\left(\mathrm{B}_{2}\right)$ for 2030, 2050, and 2100. Thereby, it was proposed spatial planning and solutions to cope with and adapt to climate change and SLR (Tien, 2015).

\section{Principle for estimating economic losses} due to ecosystem degradation

\subsection{The total economic value of typical ecosystems}

The ecosystems' functions include providing people goods and services and the use of such goods and services bring economic value to people. According to Tietenberg (2003), use values refer to the ecological goods and services that the environment provides to people and economic systems, non-use values are intrinsic, intrinsic values of the ecosystem, as shown in Fig. 1.

Direct use value includes goods and services provided by natural resources and environment and can be directly consumed such as shrimp, fish, firewood, wood, seafood, recreational tourism, medicine...

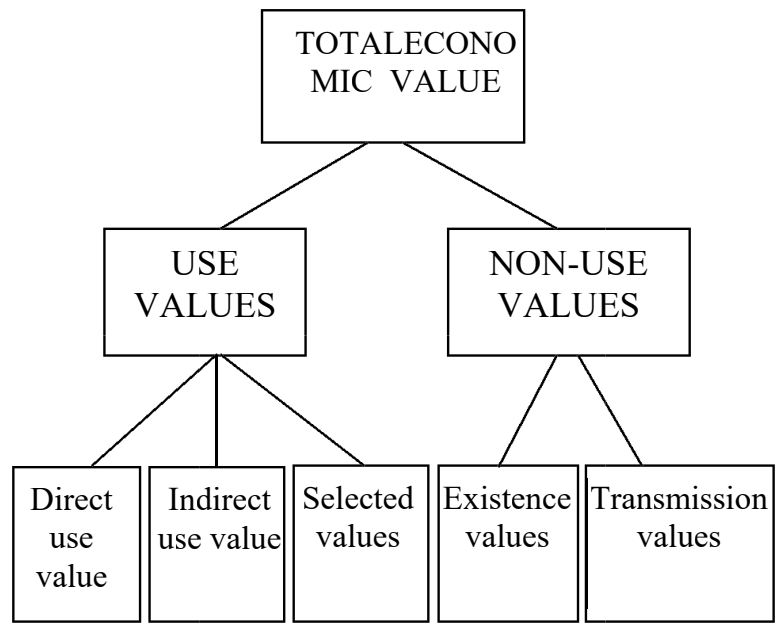

Fig. 1. The total economic value of natural resources and the environment 
Indirect use value are values and benefits from ecological services provided by the system of natural resources and environment and ecological functions such as $\mathrm{CO}_{2}$ absorption, climate control, storm prevention floods and natural disaster mitigation, filtration and regulation,...

Selected values are the values used directly or indirectly, although they can be used in the present but have not been used for some reason, leaving them for future consumption as value: tourism landscape, genetic resources, other resources...

Existence values are the values in the perception, feeling and satisfaction of individuals when knowing the properties of resources \& environment existing in a certain state. These valuesare measured by an individual's willingness to pay to obtain that status.

Transmission values are direct or indirect values that can be used by future generations. This value is also often measured by an individual's willingness to pay to conserve resources and the environment for generations to come.

Based on the above analysis, a summary of the economic value of some typical ecosystems (natural forests, corals, seagrasses and mangroves) is in Table 1.

Table 1. Total economic value of some typical ecosystems (natural forests, corals, seagrasses and mangroves)

\begin{tabular}{llll}
\hline $\begin{array}{c}\text { Direct use } \\
\text { values }\end{array}$ & $\begin{array}{c}\text { Indirect use } \\
\text { values }\end{array}$ & $\begin{array}{c}\text { Selected } \\
\text { values }\end{array}$ & $\begin{array}{c}\text { Transmiss- } \\
\text { ion values }\end{array}$ \\
\hline -Natural forests & -Preventing & - Potential & -Preserving \\
$\&$ mangroves: & floods, storm & sources of biodiversity \\
providing & barriers, storm & medicinal & Cultural, \\
energy: wood, & surges, erosion herbs & historical, \\
firewood, ... & and accretion. & - Potential & religious \\
-Mangroves, & -Providing landscape & and political \\
corals \& sea & shelter for for & values \\
grasses: & animals and tourism & -Transmiss- \\
Exploiting and plants. & ion values \\
raising aquatic & - CO & future \\
products; & absorption, & generations \\
Providing & environmental & \\
products such & conditioning. & \\
as food, & -Preventing & \\
medicine, & saline water & \\
medicine, & intrusion. & \\
construction & -Gathering, & \\
materials ... & expanding & \\
Traffic; & land & \\
Tourism, & & \\
entertainment & & \\
\hline
\end{tabular}

\subsection{Methods of estimating economic losses}

Dixon (1993) developed an approach to assess pollution/degradation/incident impacts on economic values (Fig. 1). Accordingly, economic losses will be calculated based on the difference of expenses and benefits at the two points: the baseline state (before the incident) and the state after the incident

The baseline state appears when no breakdown or degradation of the ecosystem occurs, the environmental system provides natural ecological goods and services to the economic system. When an incident/degradation occurs, the structure and function of the ecosystem's environment system will change, thereby leading to decrease or complete cutoff in the quantity and quality of goods and services provided in comparison with the baseline state. This leads to changes in the benefits and costs of individuals and society - these are the economic losses of incidents/pollution/environmental degradation and ecosystems.

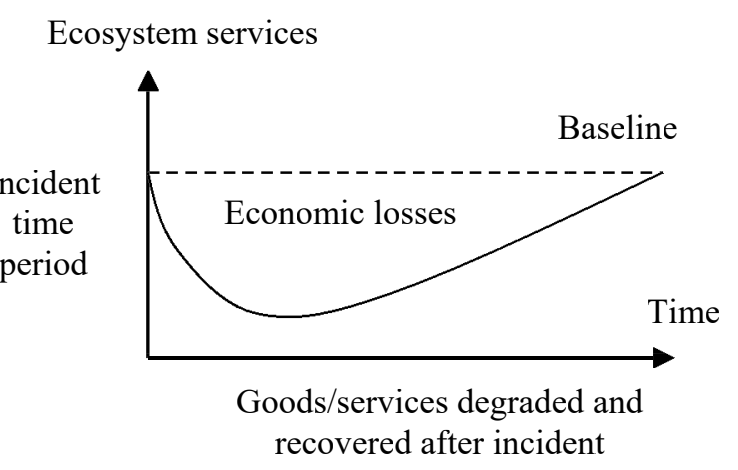

Fig. 2. Environmental economic damage due to natural and human impacts (Dixon, 1993)

To measure the economic value at the two points before and after the incident, Dixon and Sherman (1993) proposed three groups of methods: the market price method,revealed preference method, state preference method. Assessment method based on state preference method. The methods and specific objects applied are summarized and presented in Table 2 
Table 2. Methods of estimating economic losses due to environmental incidents degradation

\begin{tabular}{|c|c|c|}
\hline List & Tethods & Applications \\
\hline$I$ & & Methods of costmeasurement based on the real market \\
\hline 1.1 & $\begin{array}{l}\text { Market } \\
\text { price }\end{array}$ & $\begin{array}{l}\text { Assessing the change in quantity and quality of ecosystem goods and services } \\
\text { exchanged or traded on the market such as aquatic products, timber, } \\
\text { pharmaceuticals, etc. }\end{array}$ \\
\hline 1.2 & $\begin{array}{l}\text { Production } \\
\text { change }\end{array}$ & $\begin{array}{l}\text { Values are measured, and market prices are used to calculate inputs and outputs in } \\
\text { production and to assess physical changes in the process when there are damage } \\
\text { factors such as: ecosystem degradation reduction of biological resources (aquatic } \\
\text { products: shrimp, crabs, fish ...) living in such environment entails the influence of } \\
\text { fishermen Cs income }\end{array}$ \\
\hline 1.3 & $\begin{array}{c}\text { Health } \\
\text { costs }\end{array}$ & $\begin{array}{l}\text { Assessing the cost of illness caused by environmental pollution or damage agents } \\
\text { such as paper factory affects the health of people around the area }\end{array}$ \\
\hline 1.4 & $\begin{array}{l}\text { Recovery } \\
\text { and } \\
\text { replaceme- } \\
\text { nt costs }\end{array}$ & $\begin{array}{l}\text { Determining the value of the change in the quality of environment/resources and } \\
\text { ecosystem services is determined by the cost of restoring/replacing the lost resource } \\
\text { assets. For example: calculating economic losses due to oil pollution incidents. }\end{array}$ \\
\hline 1.5 & $\begin{array}{l}\text { Protection } \\
\text { or } \\
\text { prevention } \\
\text { costs }\end{array}$ & $\begin{array}{l}\text { Investigating the costs that people actually have to pay or are willing to pay to avoid } \\
\text { the damage that can be caused by environmental degradation such as the value of } \\
\text { mangroves in coastal erosion prevention. }\end{array}$ \\
\hline II & & Methods of da \\
\hline 2.1 & $\begin{array}{l}\text { Travelling } \\
\text { costs }\end{array}$ & $\begin{array}{l}\text { Assessing the value of outdoor recreation such as fishing, hunting, yachting and } \\
\text { sightseeing ... or assess the pollution damage by observing the change in the number } \\
\text { of visitors to a recreational destination }\end{array}$ \\
\hline 2.2 & nt & 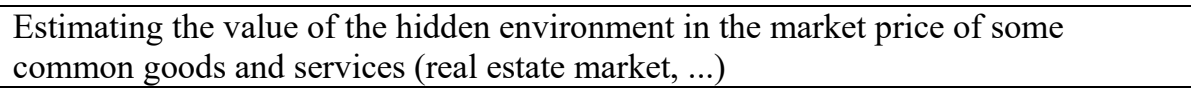 \\
\hline 2.3 & $\begin{array}{l}\text { Production } \\
\text { function }\end{array}$ & $\begin{array}{l}\text { Applicable to indirectly used values when they are in the production function of an } \\
\text { economic activity and have significant effects on the output of that economic } \\
\text { process. For example, the influence of production inputs on fishing industry and } \\
\text { aquaculture }\end{array}$ \\
\hline III & & Methods of cost measurements based on the hypothetical market \\
\hline 3.1 & $\begin{array}{l}\text { Contingent } \\
\text { valuation }\end{array}$ & $\begin{array}{l}\text { By developing a hypothetical scenario and market with information collected about } \\
\text { individual consumption behavior and choices in the hypothetical market, it is } \\
\text { possible to changes in fish welfare. Due to changes in environmental quality,factors } \\
\text { such as biodiversity damage when natural ecosystems are degraded }\end{array}$ \\
\hline 3.2 & $\begin{array}{l}\text { Choice } \\
\text { modelling }\end{array}$ & $\begin{array}{l}\text { Estimating the non use value of resources by building two or more hypothetical } \\
\text { scenarios, each with many different attributes such as developing ecosystem } \\
\text { resource use scenarios to evaluate the values / benefits of each scenario for resource } \\
\text { and environment management }\end{array}$ \\
\hline
\end{tabular}

\section{Studies on economic costs due to ecosys- tem degradation in the context of climate change}

Coral reef ecosystems have been studied by many scientists in the world to measure the economic costs due to climate change than other ecosystems (natural forests, seagrasses and mangroves). Despite, the number of studies that estimate the economic value of these ecosystems is significant. Economic values of coral reefs, mangroves, and seagrasses for global compilation were summarized (WRI, CI, NOAA, 2008), which contains a number of researches in the world on the economic values as well as economic losses due to degradation of ecosystems, especially by the impact of climate change. The deterioration of the Caribbean reefs could lead to revenue losses from fisheries, tourism and reduced coastal protection over the next 50 years.Economic losses amount in fishery from $\$ 95$ to $\$ 140$ million, tourism: 100 - 300 million $\$$, coastal protection 140 - 420 million\$ (Burkeand Maidens, 2004). Anderson (2007) investigated losses of benefits from Zanzibar coral 
ecosystem damage in Tanzania (the country on the east coast of Africa) by estimation of the tourist cost method before and after the coral bleaching incident. The annual loss due to the coral bleaching was estimated up to 15.04 million $\$$, or $\$ 254$ to $\$ 1,780$ per guest (Anderson, 2007). The damage caused by the destruction of coral reefs in Sri Lanka to induce erosion on the south and west coasts estimated at an average of $40 \mathrm{~cm}$ per year. This study used alternative cost method of coastal protection provided by coral reefs. 30.0 million\$ has been used for structures to reduce damage of coral reefs. Average cost was from 246,000 to 836,000 dollars per kilometer (Berg et al., 1998). The economic value of the mangrove ecosystem in Malasia was measured by the market price method to calculate the value of fishing and logging. Fishery value was 70 billion Rupiah/year and traditional non-commercial use value is 20 billion Rupiah/year, logging value (selective felling) is 40 billion Rupiah/year (Ruitenbeek, 1994). The economic value of mangrove ecosystems was assessed in Tha Po Village in Surat Thani Province - Southern Thailand used market price method by estimated value of firewood, timber, fisheries and replacement value method by estimated value of sea protection function. The economic value of the study area obtained from the mangrove ecosystem ranges from 27,263 USD to 35,921 USD for 1 ha (Sathirathai and Barbier, 2001). Desvousges (1998) studied the option of using the Canyon mountain (USA) between hydropower construction and tourism development. Market price method was used to calculate the net economic value of electricity production and tourism cost method was used to calculate the tourism value of the cliff. Electricity production value was 80 million USD/year but the tourist value for the result was 900 million USD/year. So this study preserved the Canyon cliff for tourism development (Desvousges, 1998). Recreation and tourism of forested areas in Europe and North America were calculated using a random measurement method through a willingness to pay mechanism. The price paid for the use of recreational and travel services by people in Europe and North America ranged from 1-3USD/person/time (David and Corin, 2001). In general, studies on the measurement of economic losses and economic values of typical natural ecosystems (natural forests, corals, seagrasses and mangroves) have been conducted by scientists and organizations around the world. Scientific research has contributed significantly to the management of ecosystem resources and environment in countries. In particular, the flexible use of economic evaluation methods creates a diverse reference source for further studies.

In Vietnam, research on cost assessment (losses) has started from the late $20^{\text {th }}$ century and early $21^{\text {st }}$ century. The measurement of economic value of natural resources and environmental impacts on the 1990s with the introduction of the 1993 Law on Environmental Protection required the identification of damage caused by pollution from environmental degradation. Lots of research was carried out on various topics and projects at various levels sharing the common goal of determining the economic value of environmental, ecosystem and public health factors under the operation of factories, industrial zones,... in particular and environmental pollution factors, due to economic development activities of each region and locality in general. A number of studies evaluated the value or economic losses due to ecosystem incidents / degradation in the context of climate change in Vietnam. Thanh (2015) conducted a research on Economic evaluation due to climate change for Northern fishery and propose solutions to minimize damage caused by climate change used method with production function (the impact model of climate change through variables of rainfall, storm, temperature, ... to the annual fishing output) and market price. Results showedthe estimated annual economic loss due to climate change to the national aquaculture is about 584 (billion VND), annual aquaculture was about 568 (billion VND) (Thanh, 2015). The loss of 
typical ecosystems (coral reef, seagrassand mangrove ecosystems) due to natural and human impacts applied incase study of 4 areas: Cua $\mathrm{Ba}$ Lat, Tam Giang - CauHai, Con Dao and Ha Long Bay. Measurement method used random measurement (economic loss valuation of non use values); market prices (calculation of economic losses of direct use values of fisheries) and travel costs methods (costcalculation of tourism values), cost of avoided losses (estimated value loss coastal protection), benefit transfer (economic losses, reduction of sediment accumulation, expansion of mangroves). Results of this study showed thatthe loss of economic value due to ecosystem degradation in the four pilot sites were respectively 5.06, 6.32, 11.05 and 6.20 billion VND (Chinh and Truong, 2011). Economic valuation of typical sea - island ecosystems for the sustainable development of a number of frontal islands in Vietnam's coastal areas. Three key research islands are Bach Long Vi (Hai Phong province), Con Co (Quang Tri province) and Tho Chu (Kien Giang province). The method used such as market price (for the value of mineral exploitation), travel expenses (for travel and sightseeing values), replacement cost (for nutritional filtration value), cost of avoided damage (protection value, erosion control), random assessment of CVM (for biodiversity values, habitats, nursery grounds for marine biomes and non-use value) and inherit the results of other relevant studies. The economic value of ecosystems in 1 year in the 3 pilot sites was 599.05, 267.52, 565.24 billion VND, respectively (Lan, 2015). On another hand, a study estimated the recreational value of Cuc Phuong National Park (National Park) for domestic tourists to assess by apply method travel expenses to calculate the recreational value of tourists visiting Cuc Phuong National Park. The total tourism benefit was 1,502 billion VND and the consumer surplus of visiting tourists was 105,415 millionVND (Thanh and Hai, 1997).

\section{Conclusion}

Based on the summary of investigations on ecosystem degradation due to climate changes, it has shown that studies in the world and in Vietnam on ecosystem degradation, especially coastal ecosystem degradations (corals, seagrasses, mangroves) are quite popular. Studies have established a set of criteria to assess the degradation of coral, seagrass and mangrove ecosystems. The main cause of degradation of these ecosystems was human impact and natural disasters such as climate change and SLR. A number of studies have selected degradation research methods and evaluated the impact of climate change on ecosystems, forecasting the degradation of ecosystems of mangroves, coral reefs and seagrasses under the scenario of climate change and offered solutions to cope with climate change as Yet (2010), Cuong and Thung (2011), An (2015), Tien et al. (2015).

In terms of research on measuring economic costs as well as evaluating the economic value of ecosystems in the world and in Vietnam, there has been a certain stage of development according to the social management requirements. The system of methods and techniques applied to measure economic costshave been increasingly addedand improved. Studies have also selected the flexible use of multiple cost measurement methods and the calculation of monetary damages. However, studies measuring economic losses due to ecosystem degradation in the world and in Vietnam are still limited. An equally important factor causing economic damage to ecosystems is climate change, which is rarely mentioned.

\section{References}

1. An, N.D., Giang, D.H., Huong, N.T.M., 2015. Studying and assessing the impact of climate change on some typical islands and groups of islands of Vietnam and proposing solutions. BĐKH 50/11-15. Ministry of Natural Resource and Environment.

2. Andersson, J.E.C., 2007. The recreational cost of coral bleaching: A stated and revealed preference study of international tourists. Ecol. 
Overview of investigations in economic loss by ecosystem degradation relating to climate change

Econ., 62: 704-715.

3. Berg, H., Öhman, M.C., Troëng S., Lindén. O., 1998. Environmental economics of coral reef destruction in Sri Lanka. Ambio, 27: 627-634.

4. Brian, D.K., Gleason, D.F., McLeod, E., Woodley, C.M., Airamé, S., Causey, B.D., Friedlander, A.M. Grober-Dunsmore, R., Johnson, J.E., Miller, S.L., Steneck, R.S., 2009. Climate Change, Coral Reef Ecosystems, and Management Options for Marine Protected Areas. Environ Manage., 44 (6): 1069-1088.

5. Burke, L., Maidens, J., 2004. Reefs at Risk in the Caribbean. World Resources Institute.

6. Charlotte, S., 2007. Protecting forests to mitigate global climate change. https://www.illegal-logging.info/

7. Chinh, N.T., Truong, D.D., 2011. Assessment of the loss of typical marine ecosystems (ecosystems of coral reefs, seagrass and mangroves) due to natural and human impacts. Report of project: Investigating, assessing and forecasting the extent of loss, degradation and resilience and recovery of coral reefs, sea grass beds and mangroves in Vietnam's coastal areas and coastal areas; Proposing protection solutions towards sustainable development.Vietnam Environment Administration.

8. Cuong. P.A., Thung, D.C., 2011. Investigating, assessing and forecasting the extent of loss, degradation and resilience and recovery of coral reef, seagrass and mangrove ecosystems in Vietnam's coastal and coastal areas; Proposing protection measures towards sustainable development. Report of project: Investigating and evaluating the vulnerability of natural resources - the environment and marine meteorology in Vietnam; forecasting natural disasters and environmental pollution in sea areas.

9. David, W.P., Corin, G.T.P., 2001. The Value of Forest Ecosystems. A Report to The Secretariat Convention on Biological Diversity.

10. Dixon, J.A., Sherman, P.B., 1993. Economic Analysis of Environmental Impacts. Earthscan Publications Ltd, London, UK.

11. Desvousges, W.H., Spencer, H.S., 1998.
Environmental Analysis with Limited Information, Edward Elgar Publishing, UK

12. Field, C.D., 1995. Impact of expected climate change on mangroves. Hydrobiologia, 295: 75- 81 .

13. Gilman, E., Joanna, E., Richard, C., 2007. Assessment of Mangrove Response to Projected Relative Sea-level Rise and Recent Historical Reconstruction of Shoreline Position. Environ Monit. Assess., 124: 105-130.

14. Inkyin, K., Su, Y.W., 2014. An overview of interrelationship between climate change and forests. Forest Science and Technology, 11 (1): 11-18.

15. IPCC, 2007a. Summary for Policy Makers - Climate Change 2007: The Physical Science Basis. Contribution of Working Group I. In: Solomon, S. et al., (Eds.). Fourth Assessment Report of the Intergovernmental Panel on Climate Change (Authors: Alley Richard et al.). Cambridge University Press, UK and USA, pp 18.

16. Lan, T.D., 2015. Economic evaluation of typical sea-island ecosystems for the sustainable development of a number of frontal islands in Vietnam's coastal areas. KC09.08/11-15. Institute of Marine Resources and Environment.

17. Mireia, V., Guillem, C., Andreadel, C., Mary, S.W., Steffen, M.O., Joxe, M.G., Ángel, B., 2014. Projecting future distribution of the seagrassZosteranoltii under global warming. Biological Conservation, 170: 74-85.

18. Phương, V.T., 2006. Environmental value and forest environmental services. Vietnam Journal of Agriculture and Rural Development, 15: 7-11.

19. Ruitenbeek, H.J, 1994. Modelling economy-ecology linkages in mangroves: Economic evidence for promoting conservation in Bintuni Bay, Indonesia. Ecological Economics, 10 (3): 233-247.

20. Sathirathai, S., Barbier, E.B., 2001. Valuing mangrove conservation in southern Thailand. Contemporary Economic Policy, 19 (2), 109-122.

21. Short, F.T., Neckles, H.A., 1999. The ef- 
fects of global climate change on seagrasses. NewYork. Aquat. Bot., 63: 169-196.

22. Thanh, N.D., Hai, L.T., 1997. Estimating the recreational value of Cuc Phuong National Park using the method of tourism costs, Environmental economic studies, Economy and Environment Program for Southeast Asia (EEPSEA).

23. Thanh, N.N., 2015. Assessing the economic value of climate change for Northern fishery and proposing solutions to minimize damage caused by climate change. BĐKH-25/11-15. University of Economics and Business - Vietnam National University, Hanoi.

24. Tien, D.M., 2015. Impacts of climate change, sea level rise on natural, socio-economic system and spatial planning orientation of Nhon Hoi and BinhDinh open economic zones. Science \& Technology Publishing House.

25. Tietenbery, T., 2003. Environmental and Natural Resource Economics. Harper Collins,

26. Truong, D.D., Nga, N.V., 2013. Agricultural damage caused by industrial pollution: The case of Sonadezi Long Thanh industrial park, Dong Nai province.

27. World Resources Institute (WRI), Conservation International (CI), the United States National Oceanic and Atmospheric Administration (NOAA), 2008. The booklet "Economic Values of Coral Reefs, Mangroves, and Seagrasses: A Global Compilation”.

28. Yet, N.H., 2010. Assessment of the degradation of ecosystems in coastal areas of Vietnam and proposing solutions for sustainable management. KC.09.26/06-10. Institute of Marine Resources and Environment.

29. http://www.vasi.gov.vn/tin-tong-hop/hesinh-thai-bien-viet-nam-truoc-tac-dong-cuabien-doi-khi-hau/t708/c223/i535

30. https://www.cbd.int/ 